\title{
POLA SEBARAN PERMUKIMAN KUMUH (STUDI KASUS : KECAMATAN SEMARANG UTARA KOTA SEMARANG)
}

\author{
Aspin Aspin*1, Nur Nafsi ${ }^{2}$ \\ Arsitektur, Universitas Halu Oleo ${ }^{1,2}$ \\ e-mail: *1aspin_arsitektur@uho.ac.id,2nurnafsilatif@gmail.com
}

\begin{abstract}
Abstrak_ Kecamatan Semarang Utara merupakan Kecamatan dengan potensi sosial ekonomi yang tinggi karena didalamnya terdapat pelabuhan, stasiun kereta api dan kawasan-kawasan komersial, potensi sosial ekonomi yang tinggi menyebabkan tingginya aktivitas di lokasi tersebut. Akibatnya wilayah tersebut menarik untuk dijadikan sebagai tempat bermukim, seiring berjalannya waktu banyak pendatang yang ingin tinggal dan menetap di wilayah tersebut, yang kemudian berimbas pada meningkatnya kebutuhan lahan, dan akhirnya mendirikan bangunan di lahan-lahan yang terbatas dan berpotensi untuk menimbulkan kawasan-kawasan kumuh.Penelitian ini bertujan untuk mengetahui Pola Sebaran Permukiman Kumuh di Kecamatan Semarang Utara.Untuk mencapai tujuan tersebut dilakukan analisis pola sebaran permukiman kumuh yang meliputi sebaran permukiman kumuh dan bentuk-bentuk permukiman kumuh.Dalam penelitian ini menggunakan metode deskriptif kualitatif dengan pendekatan rasionalistik. Terdapat 10 titik sebaran permukiman kumuh di Kecamatan Semarang Utara, 6 titik sebaran kawasan kumuh diantaranya membentuk pola permukiman terpusat atau mengelompok, dan 4 titik sebaran kawasan kumuh lainnya membentuk pola permukiman linier mengikuti jalan, mengikuti sungai dan rel kereta api. Kawasan kumuh tersebut cenderung tumbuh mendekati sekitar kawasan industri, kawasan sempadan sungai, kawasan pasar, kawasan pelabuhan, stasiun dan rel kereta api.
\end{abstract}

Kata Kunci: Permukiman Kumuh; Sebaran Permukiman; Pola Permukiman.

\begin{abstract}
North Semarang Sub-district is a sub-district with high socio-economic potential. There are ports, railway stations, and commercial areas; high socio-economic potential causes high location. As a result, the site is interesting to be used as a place to live; as the passage of time, many migrants want to stay and settle in the area, which then impacts on the increasing demand for land, and eventually builds buildings on limited grounds and potentially to cause slum areas. This research aims to find out the pattern of the distribution of slum settlements in the North Semarang District. To achieve these objectives, several analyses are analyzed for slum settlement patterns covering the distribution of slums and slum forms - this research using the qualitative descriptive method with a rationalistic approach. There are 10 points of distribution of slum settlements in the North Semarang Sub-district, 6 spots of slum areas among them form a centralized or clustered settlement pattern, and four other spots of slum areas form a linear settlement pattern following the road, following the rivers and railways. The slum areas tend to grow close to industrial areas, riverbanks, market areas, port areas, stations, and railways.
\end{abstract}

Keywords: Slum Settlement; Distribution Of Settlements; Settlement Patterns.

\footnotetext{
Arsitektur, Universitas Halu Oleo

${ }^{2}$ Arsitektur, Universitas Halu Oleo
} 


\section{PENDAHULUAN}

Pada umumnya suatu kotaberawal dari permukiman yang kecil, dan secara spasial mempunyai lokasi strategis bagi kegiatan perdagangan (Sandy, 1978 dalam Auliannisa, 2009). Berkembangnya suatu kota merupakan proses perubahan kota dari suatu keadaan ke keadaan yang lain dan dalam kurun waktu yang berbeda,perbedaanyang dapat dicirikan adalah jumlah penduduknya yang semakin meningkat dan perlahan-lahan menjadi padat penduduk, bangunanbangunannya yang makin rapat,serta wilayah terbangun terutama permukiman yang cenderung semakin luas, lengkapnya sarana dan prasarana kota menjadi pendukung utama bagi kegiatan kota terutama kegiatan sosial dan ekonomi kota (Branch, 1996 dalam Auliannisa, 2009).

Pertumbuhan populasi (manusia) akibat urbanisasi sangat mempengaruhi perkembangan pembangunan di Kota Semarang, terutama para pendatang yang akhirnya menetap.Perkembangan pembangunan di semua sektor lingkungan perkotaan adalah akibat gelombang urbanisasi yang dipacu oleh pembangunan fisik sarana dan prasarana kota yang merupakan daya dorong sekaligus daya tarik bagi para warga yang ingin memperoleh peluang kehidupan yang lebih baik. Laju pembangunan itu pula yang menyebabkan perkembangan kota seolah tanpa arah (Urban Sprawl) (Saraswati, 2001 dalam Auliannisa, 2009).

Tingginya jumlah penduduk di pusat kotamengisyaratkan harus terpenuhinya kebutuhan akan permukiman yang layak huni, khususnya untuk menampung kaum urbanis yang pekerjaannya terpusat pada sektor perdagangan dan jasa di kawasan komersial yang ada di pusat kota. Ketersediaan sarana dan prasarana yang lengkap di pusat kota ini menimbulkan daya tarik bagi masyarakat untuk bermukim di kawasan tersebut (Surtiani, 2006).

Kecamatan Semarang Utara merupakan kecamatan dengan potensi sosial ekonomi yang tinggi karena didalamnya terdapat pelabuhan, stasiun kereta api dan kawasan-kawasan komersial, potensi sosial ekonomi yang tinggi menyebabkan tingginya aktivitas di lokasi tersebut. Akibatnya wilayah tersebut menarik untuk dijadikan sebagai tempat bermukim, seiring berjalannya waktu banyak pendatang yang ingin tinggal dan menetap di wilayah tersebut, yang kemudian berimbas pada meningkatnya kebutuhan lahan, dan akhirnya mendirikan bangunan di lahan-lahan yang terbatas dan berpotensi untuk menimbulkan kawasan-kawasan kumuh.

Berdasarkan data kawasan kumuh di Kota Semarang sesuai dengan SK Walikota pada tahun 2014 terkait penetapan lokasi kawasan perumahan dan permukiman kumuh di Kota Semarang menerangkan bahwa dari 16 jumlah Kecamatan di Kota Semarang, 15 Kecamatan diantaranya masuk dalam deliniasi permukiman kumuh yang luasnya mencapai 415, 83 Ha, dengan luas permukiman kumuh terbesar berada di Kecamatan Semarang Utara yang luasnya mencapai 147, 4 Ha yang tersebar di beberapa kelurahan di Kecamatan Semarang Utara.Adapun tujuan dari penelitian ini yaitu untuk menemukanpola sebaran permukiman kumuh di Kecamatan Semarang Utara.

\section{METODE}

Penelitian ini menggunakan metode deskriptif kualitatif melalui pendekatan rasionalistik.Metode deskriptif merupakan suatu metode yang digunakan untuk meneliti suatu objek, status sekelompok manusia, suatu kondisi, suatu sistem pemikiran ataupun suatu kelas peristiwa pada masa sekarang.Tujuan dari penelitian deskriptif ini yaitu untuk membuat 
gambaran, deskripsi, atau lukisan secara sistematis, faktual dan akurat mengenaisifat-sifat, faktafakta serta hubungan antarfenomena yang diteliti (Nazir, 1988).

Penelitian kualitatif merupakan penelitian yang memanfaatkan latar alamiah dengan tujuan mengartikan fenomena yang terjadiyang dilakukan dengan cara menggunakan berbagai metode yang ada (Denzin dan Lincoln, 1987 dalam Gumilang, 2016).

Penelitian kualitatif merupakan penelitian yang bertujuan untuk memahami kejadian tentang apa yang dialami oleh subjek penelitian secara holistik dengan cara menggambarkan dalam bentuk kata-kata dan bahasa, pada suatu kerangka khusus yang alamiah dan dengan menggunakan berbagai metode alamiah.

Metodologi penelitian yang digunakan dalam penelitian ini melalui pendekatan rasionalistik.Desain penelitian rasionalistik berawal dari kerangka teoritik yang dibangun dari penafsiran terhadap hasil penelitian terdahulu, teori-teori yang diketahui, hasil pikiran para ahli, dan disimpulkan menjadi sesuatu yang mengandung sejumlah masalah yang perlu diteliti lebih lanjut.Dimana metodologi penelitian kualitatif rasionalistik ini berawal dari penghampiran holistik berupa grand concepts yang dijelaskan menjadi teori substantif. Obyek diteliti tanpa dilepaskan dari konteksnya dalam fokus/penekanan tertentu dan hasil penelitiannya digunakan kembali pada grand concepts (Muhadjir, 1996)

Tahapan analisis yang dilakukan untuk menemukan pola sebaran permukiman kumuh di Kecamatan Semarang Utara yaitu diawali dengan menelaah seluruh data yang terkumpul dari berbagai sumber, seperti dari wawancara,gambar, foto, pengamatan yang sudah ditulis dalam catatan lapangan, dokumen pribadi, dokumen resmi, citra satelit dan sebagainya, sehingga menghasilkan analisis secara luas, umum serta terperinci mengenai pola sebaran permukiman kumuh di Kecamatan Semarang Utara.

\section{HASIL DAN PEMBAHASAN}

\section{A. Pola Permukiman}

Pola (pattern) dapat didefinisikan sebagai susunan gambar, corak,struktural, kombinasi sifat kecenderungan yang membentuk sesuatu yang taat asas dan bersifat khusus (Depdikbud, 1988 dalam Auliannisa 2009), dan dapat juga didefinisikan sebagai benda yang tersusun menurut sistem tertentu mengikuti kecenderungan bentuk tertentu. Sedangkan dalam Kamus Besar Bahasa Indonesia, pola adalah model, sistem, cara kerja atau bentuk (struktur) yang tetap.

Pola permukiman beragam tergantung pada lokasi permukiman dan mata pencaharian penduduknya.Daldjoeni (2003) danWulan(2016) mengklasifikasikan pola-pola permukiman secara sederhana. Terdapat tiga macam pola permukiman, yaitu pola permukiman menyebar (dispersed), pola permukiman terpusat (nucleared) dan pola permukiman memanjang (linear).

Pola permukiman menunjukan tempat manusia untuk tinggal dan menetap dan melakukan kegiatan atau aktivitasnya sehari-hari.Permukiman dapat didefinisikan sebagai tempat (ruang) atau suatu wilayah dimana masyarakat terfokus dan tinggal bersama-sama memanfaatkan lingkungan tersebut, untuk melakukan, menjaga atau melindungi, dan mengembangkan hidupnya. Dwi Ari \& Antariksa (2005) dan Novitasari(2011) mengklasifikasikan pola permukiman berlandaskan bentuknya terdiri dari beberapa bagian, antara lain: 
1. Pola permukiman bentuk memanjang (linier), terdiri dari memanjang jalan, sungai, dan garis pantai.

2. Pola permukiman bentuk melingkar.

3. Pola permukiman bentuk persegi panjang.

4. Pola permukiman bentuk kubus.

Pola spasial permukiman menurut Wiriaatmadja (1981)dan Pasundanie (2009) antara lain:

1. Pola permukiman dengan cara tersebar berjauhan antara permukiman yang satu dengan yang lain, terutama terjadi dalam wilayah yang baru dimanfaatkan. Hal ini disebabkan karena belum ada jalan besar,sedangkan penduduknya mempunyai sebidang tanah yang dalam suatu waktu harus dimanfaatkan secara turun temurun.

2. Pola permukiman dengan cara berkumpul dalam sebuah kampung atau desa, memanjang mengikuti jalan (jalan darat atau sungai), sedangkan tanah yang dimanfaatkan berada di sekelilingnya.

3. Pola permukiman dengan cara terkumpul dalam sebuah kampung atau desa, sedangkan tanah yang dimanfaatkan berada di luar kampung.

4. Berkumpul dan tersusun melingkar mengikuti jalan. Pola permukiman dengan cara berkumpul dalam sebuah kampung atau desa, mengikuti jalan yang melingkar, sedangkan lahan yang dimanfaatkan berada disekelilingnya.

Berikut merupakan gambaran pola spasial permukiman yang tersusun menurut Wiriaatmadja (1981) dan Pasundanie (2009) pada gambar 1:

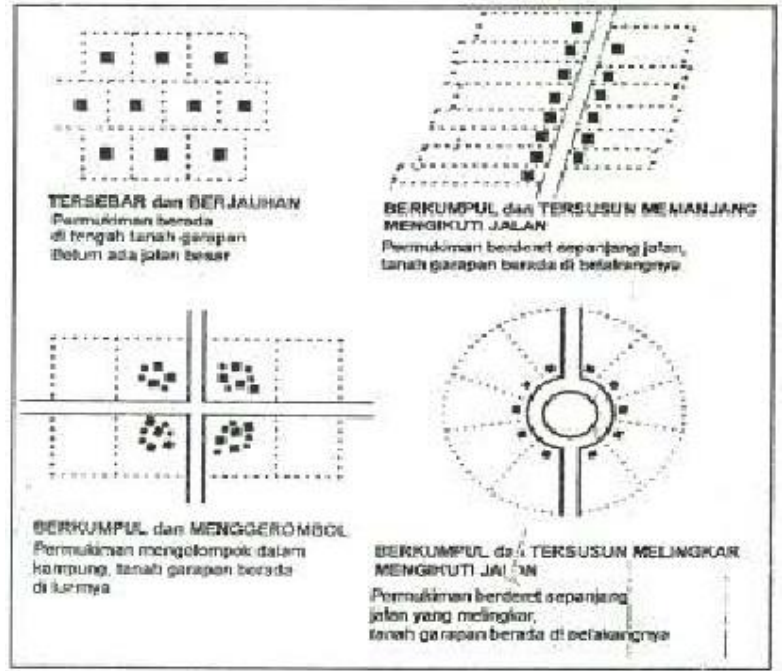

Gambar 1. Tipe-tipe Pola Permukiman Sumber: Wiriaatmadja, 1981 dalam Pasundanie 2009

\section{B. Pola Sebaran Permukiman}

Persebaran permukiman membahasterkait hal dimana terdapat atau tidak terdapat permukiman di dalam suatu wilayah (Ritohardoyo, 1991 dalam Auliannisa, 2009).

Pola persebaran permukiman mengelompok terjadi apabila darisatuan unit permukiman mengelompok secara kompak, sedangkan pola persebaran permukiman menyebar terjadi apabila jarak antar satuanunit permukiman yang satu dengan yang lainnya cukup panjang dalam suatu kelompok Hagget(1970) dan Auliannisa (2009). 
Secara umum perbedaan antara pola sebaran permukiman mengelompok, dengan pola sebaran permukiman menyebar yaitu pola sebaran permukiman mengelompok tersusun dari dusun-dusun atau bangunan-bangunan rumah yang lebih kompak dengan jarak tertentu, sedangkan pola sebaran permukiman menyebar terdiri dari dusun-dusun atau bangunanbangunan rumah yang tersebar dengan jarak tidak tertentu (Hudson, 1970 dan Landoala, 2013).

\section{Pola Sebaran Permukiman Kumuh Kecamatan Semarang Utara}

\section{Pola Sebaran Permukiman Kumuh Kelurahan Tanjung Mas}

Sebaran permukiman Kumuh di Kelurahan Tanjung Mas dimana di kawasan ini terdapat dua titik kawasan permukiman kumuh yang menyebar di kawasan Kebonharjo dan kawasan Tambaklorok. Pola permukiman di Kelurahan ini membentuk pola permukiman yang memusat atau mengelompok terhadap pasar dimana disekelilingnya terdapat industriindustri, pelabuhan dan stasiun kereta api, rel kereta api dan didalam kawasan permukimannya dilewati oleh sungai. Permukiman di Kelurahan tanjung Mas didirikan di kawasan Kebonharjo dan di Kawasan Tambaklorok dengan memanfaatkan lahan-lahan kosong legal maupun ilegal yang dulunya belum terbangun untuk mendirikan bangunanbangunan tempat tinggal warga.Hingga saat ini pendirian bangunan tersebut terus berkembang dengan keadaan bangunan yang tidak layak huni dan infrastruktur yang kurang memadai hingga membentuk suatu kawasan permukiman kumuh.

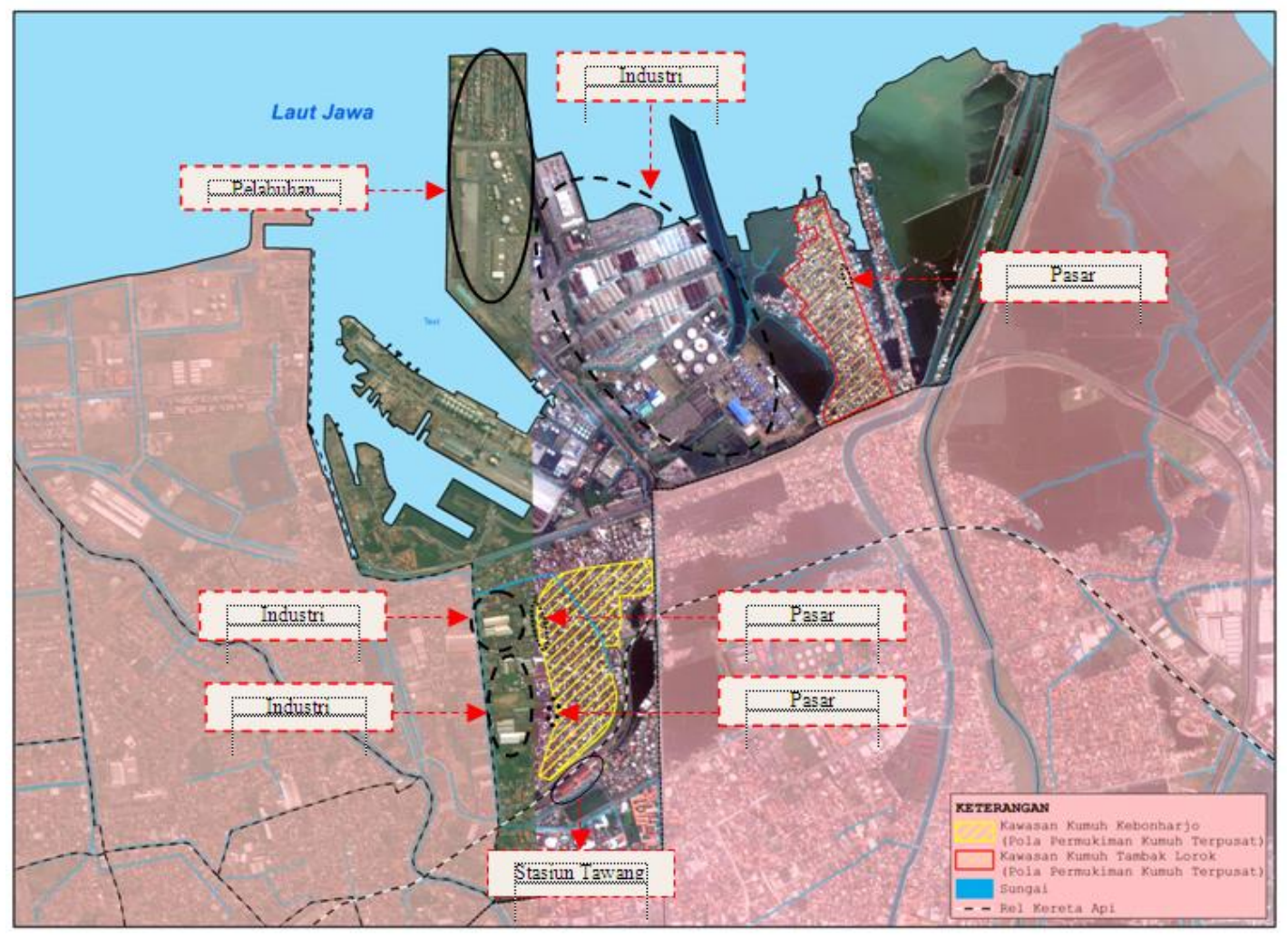

Gambar 2.Peta Pola Sebaran Permukiman Kumuh Kelurahan Tanjung Mas Sumber: Hasil Analisis, Tahun 2018

Sebaran permukiman kumuh di Kelurahan Tanjung Mas cenderung mendekati kawasankawasan industri, sarana transportasi utama (Pelabuhan Tanjung Mas dan Stasiun Tawang), 
kawasan-kawasan pasar, rel kereta api dan kawasan disekitar sempadan sungai. Pemilihan lokasi bermukim ini dipengaruhi oleh mata pencaharian atau pekerjaan warga yang tinggal di kawasan tersebut sehingga warga memilih kawasan ini untuk memudahkan mereka dalam kegiatannya terkait dengan mata pencahariannya.Selain itu ketersediaan lahan legal mau pun ilegal di kawasan ini menjadi pengaruh yang sangat besar terhadap perkembangan permukiman kumuh karena masyarakat lebih cenderung memilih untuk membangun rumah di lahan yang belum dimanfaatkan hingga membentuk suatu permukiman yang dimana bangunan-bangunannya padat dengan ruang-ruang yang sempit.

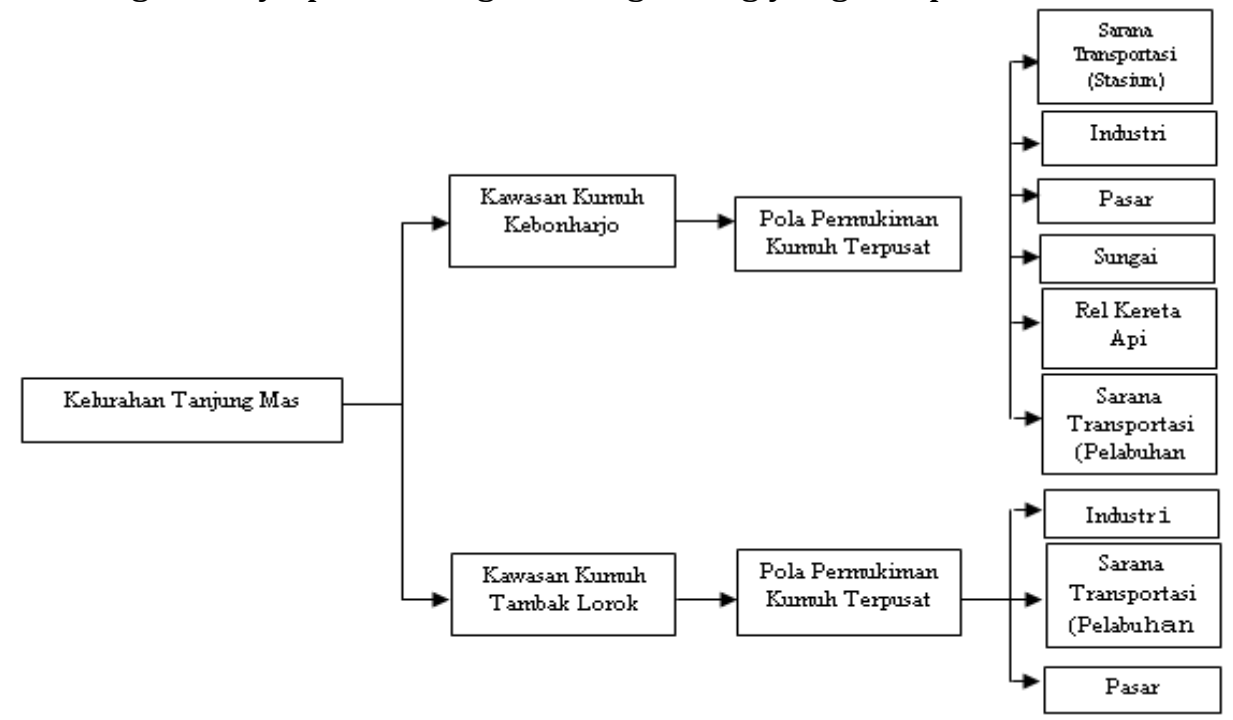

Gambar 3. Diagram Pola Sebaran Permukiman Kumuh Kelurahan Tanjung Mas Sumber: Hasil Analisis, Tahun 2018

\section{Pola Sebaran Permukiman Kumuh Kelurahan Bandarharjo.}

Sebaran permukiman Kumuh di Kelurahan Bandarharjo terdapat dua titik sebaran permukiman kumuh yang membentuk pola permukiman kumuh terpusat atau mengelompok terhadap pasar dimana disekelilingnya terdapat industri, dan pola permukiman linier mengikuti jalan, dimana di kawasan ini terdapat dua titik kawasan permukiman kumuh yang dua kawasannya terpisahkan oleh jalan arteri. Sebaran permukiman kumuh di Kelurahan Bandarharjo ini dipengaruhi oleh wilayah administrasi kelurahan yang terpisahkan oleh jalan arteri, sehingga perkembangan permukiman kumuh tersebut berada pada bagian-bagian permukiman yang dipisahkan oleh jalan arteri tersebut.Pola permukiman linier dan pola permukiman terpusat tersebut terbentuk secara alami tanpa ada perencanaan sebelumnya sehingga membentuk dua kawasan permukiman kumuh dengan kondisi infrastruktur yang kurang memadai. 


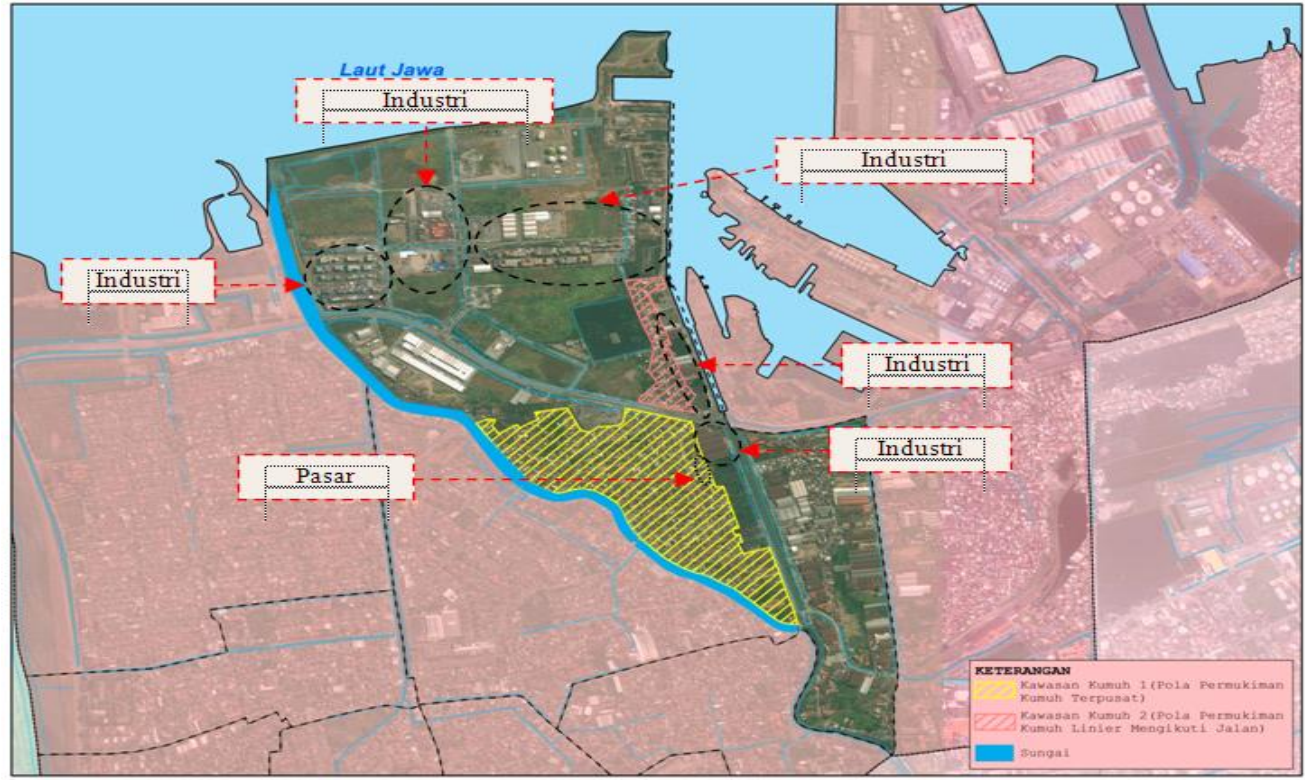

Gambar 4.Peta Pola Sebaran Permukiman Kumuh Kelurahan Bandarharjo Sumber: Hasil Analisis, Tahun 2018

Pola sebaran permukiman kumuh di kelurahan Bandarharjo cenderung mengikuti perkembangan pasar, industri dan sungai.Hal ini ditandai dengan adanya ketiga hal tersebut yang tumbuh dekat dengan kawasan permukiman kumuh membuat permukiman semakin berkembang dengan jumlah yang padat. Pola sebaran ini juga di tandai dengan beberapa titik yang menunjukan adanya ketiga faktor yang tidak mengelompok atau dalam kata lain ketiga hal tersebut tumbuh dengan menyebar akhirnya perkembangan permukiman tumbuh dengan mengikuti arus perkembangannya. Sebaran permukiman juga dipengaruhi dengan adanya tanah atau lahan legal maupun ilegal yang belum dimanfaatkan sehingga banyaknya rumah kumuh yang dibangun di atas tanah atau lahan tersebut menjadikan permukiman kumuh tumbuh.Tanah atau lahan yang belum dimanfaatkan ini pada kondisinya berada dekat dengan pasar, sungai, dan industri sehingga bangunan-bangunan yang ada memberikan kesan kumuh dengan ruang yang sesak.

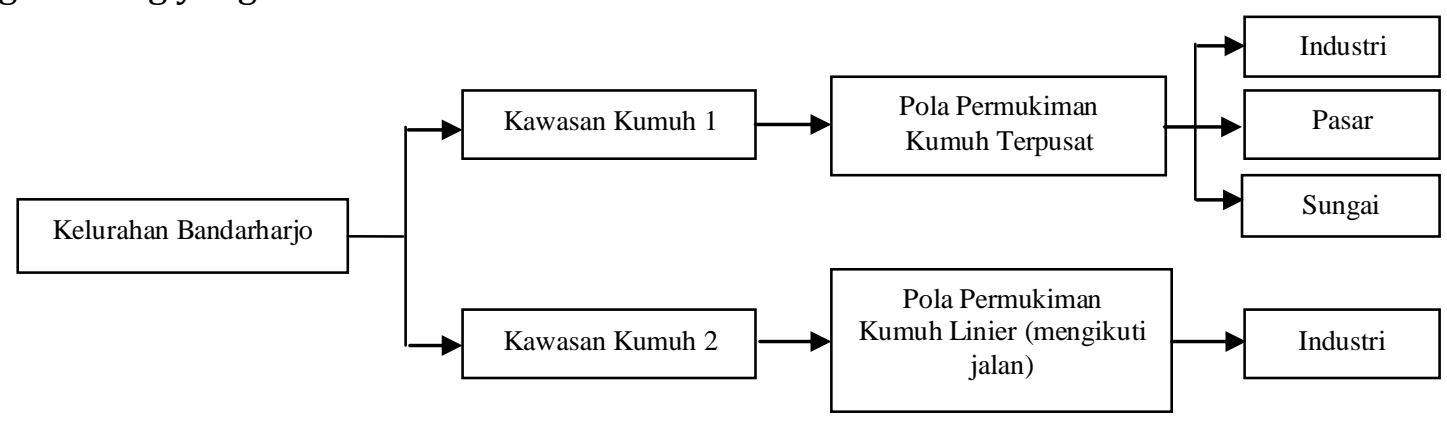

Gambar 5. Diagram Pola Sebaran Permukiman Kumuh Kelurahan Bandarharjo Sumber: Hasil Analisis, Tahun 2018 


\section{Pola Sebaran Permukiman Kumuh Kelurahan Kuningan.}

Sebaran permukiman Kumuh di Kelurahan Kuningan terdiri atas dua titik sebaran pada Kelurahan ini, dimana pola permukiman kumuh di kawasan ini membentuk pola permukiman terpusat atau mengelompok terhadap industri dan pasar dan linier (Mengikuti sungai) yang dua kawasannya terpisahkan oleh Kawasan perumahan dan jasa. Jarak antara titik permukiman kumuh yang satu dan titik permukiman kumuh yang kedua berjarak $\pm 500 \mathrm{~m}$, dalam jarak tersebut berdiri bangunan-bangunan perumahan dan jasa yang tidak masuk dalam kawasan permukiman kumuh.Karena kawasan permukiman kumuh tersebut tidak masuk dalam kawasan perencanaan perumahan yang ada disekitarnya atau dapat dikatakan permukiman kumuh tersebut tumbuh diluar kawasan perumahan yang tidak terencana membuat permukiman tumbuh tidak terarah dan tidak terkontrol dengan kondisi bangunan-bangunan yang padat dan infrastruktur yang kurang memadai sehingga mengakibatkan berkembangnya permukiman kumuh.

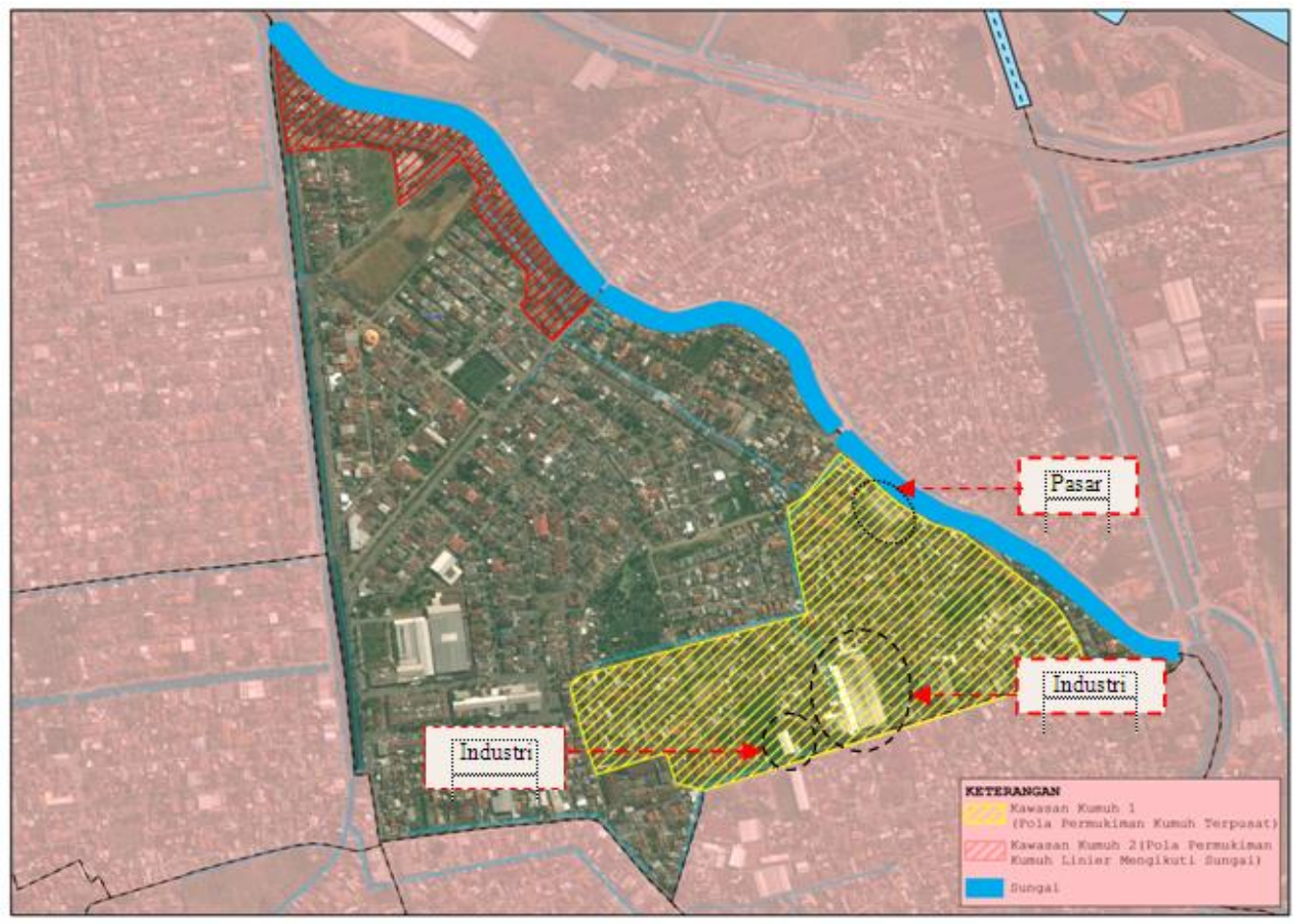

Gambar 6. Peta Pola Sebaran Permukiman Kumuh Kelurahan Kuningan Sumber: Hasil Analisis, Tahun 2018

Sebaran permukiman kumuh di Kelurahan kuningan cenderung mendekati kawasan industri, kawasan pasar, dan kawasan disekitar sempadan sungai.Hal ini ditandai dengan adanya ke tiga hal tersebut yang tumbuh berdekatan dengan kawasan permukiman kumuh membuat permukiman semakin berkembang dengan jumlah yang padat.Sebaran permukiman juga dipengaruhi dengan adanya tanah atau lahan yang belum dimanfaatkan sehingga banyaknya rumah kumuh yang dibangun di atas tanah atau lahan tersebut menjadikan permukiman kumuh tumbuh.Tanah atau lahan yang belum dimanfaatkan ini pada kondisinya berada dekat dengan pasar, sungai, dan industri sehingga membentuk suatu permukiman kumuh. 


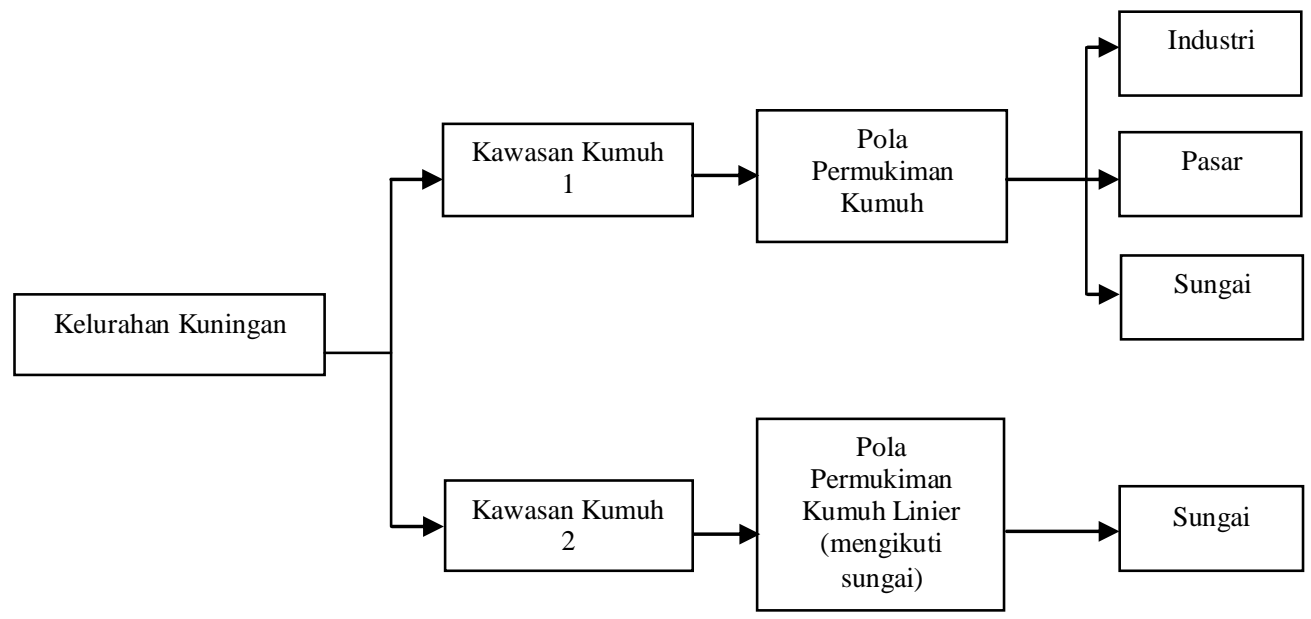

Gambar 7. Diagram Pola Sebaran Permukiman Kumuh Kelurahan Kuningan Sumber: Hasil Analisis, Tahun 2018

\section{Pola Sebaran Permukiman Kumuh Kelurahan Dadapsari.}

Sebaran permukiman Kumuh di Kelurahan dadapsari membentuk suatu pola permukiman kumuh terpusat atau mengelompok terhadap industri dan pasar, dimana kawasan ini hanya terdapat satu titik kawasan permukiman kumuh yang memusat disatu kawasan permukiman.Pola memusat atau mengelompok ini di sebabkan oleh kondisi permukiman yang disekitarnya merupakan gedung-gedung perkantoran, sehingga permukiman kumuh tumbuh dengan memusat dan mengelompok di satu titik.Pola permukiman terpusat atau mengelompok ini juga dipengaruhi oleh kepemilikan tanah yang dimiliki secara turun temurun sehingga perkembangan permukiman mengarah pada seluru penjuru tanpa terencana sesuai dengan pertambahan penduduk di kawasan kumuh tersebut.Pola permukiman yang membentuk pola permukiman terpusat atau mengelompok tersebut pada dasarnya dalam kondisi rumah yang jaraknya saling berdekatan, dan infrastruktur yang kurang memadai, hal ini sesuai dengan kondisi permukiman kumuh yang berada di Kelurahan Dadapsari.

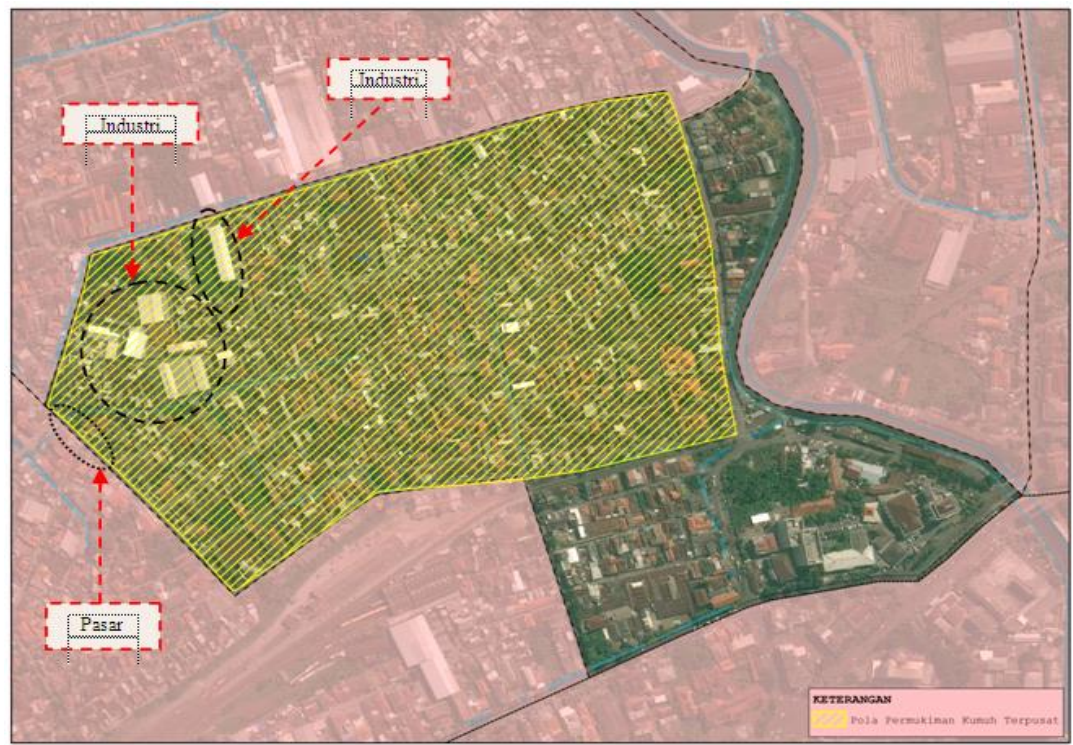

Gambar 8. Peta Pola Sebaran Permukiman Kumuh Kelurahan Dadapsari Sumber: Hasil Analisis, Tahun 2018 
Sebaran permukiman kumuh di Kelurahan Dadapsari merupakan sebaran permukiman yang membentuk pola permukiman kumuh terpusat atau mengelompok yang didalam kawasan kumuhnya terdapat pasar dan industri, sebaran permukiman juga dipengaruhi dengan adanya tanah atau lahan legal yang dulunya belum dimanfaatkan sehingga banyak rumah kumuh yang dibangun di atas lahan tersebut menjadikan permukiman kumuh tumbuh. Tanah atau lahan legal yang belum dimanfaatkan ini pada kondisinya berada dekat dengan pasar dan industri sehingga banyak rumah terbangun dalam kondisi padat dengan ruang-ruang yang sempit hingga membentuk suatu permukiman kumuh.

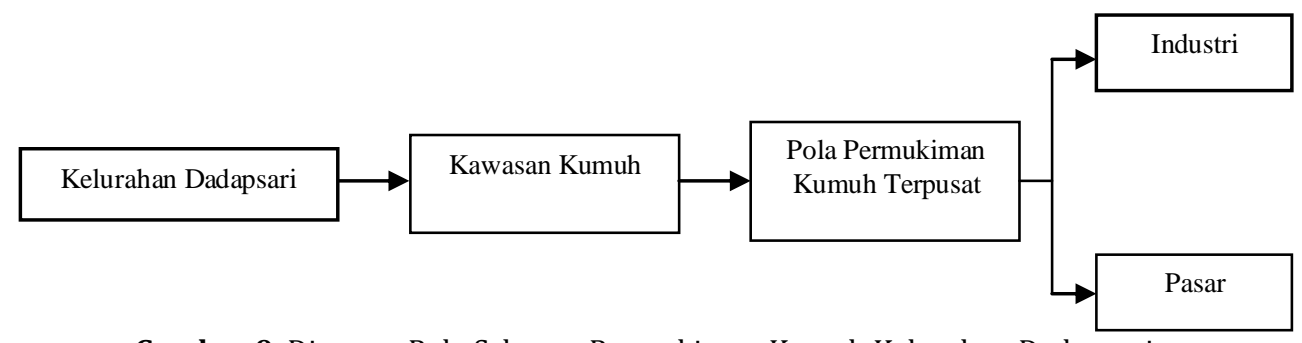

Gambar 9. Diagram Pola Sebaran Permukiman Kumuh Kelurahan Dadapsari Sumber: Hasil Analisis, Tahun 2018

\section{Pola Sebaran Permukiman Kumuh Kelurahan Panggung Kidul.}

Sebaran permukiman Kumuh di Kelurahan Panggung Kidul membentuk suatu pola permukiman kumuh terpusat atau mengelompok terhadap industri, dimana di kawasan ini hanya terdapat satu titik kawasan permukiman kumuh yang tumbuh secara terpusat atau mengelompok di satu kawasan permukiman. Pola permukiman terpusat ini tidak tumbuh secara sengaja dan terencana, permukiman kumuh ini tumbuh seiring dengan pertambahan penduduk baik penduduk lokal maupun penduduk yang melakukan migrasi masuk (in) di Kelurahan Panggung Kidul dan membangun rumah dengan kondisi lahan yang terbatas seiring dengan pertambahan penduduk tersebut. Rumah-rumah yang dibangun di kawasan permukiman tersebut berdiri di atas lahan yang harganya terjangkau sehingga menarik minat warga untuk membeli dan membuat rumah yang kecil dan penyebab lainnya adalah faktor pekerjaan karena sebagian warga bekerja sebagai buruh industri di kelurahan tersebut.Atas alasan itulah banyak warga yang membangun rumah di kawasan permukiman ini hingga membentuk pola permukiman kumuh terpusat atau mengelompok dengan keadaan permukiman yang sekarang dalam kondisi kumuh.

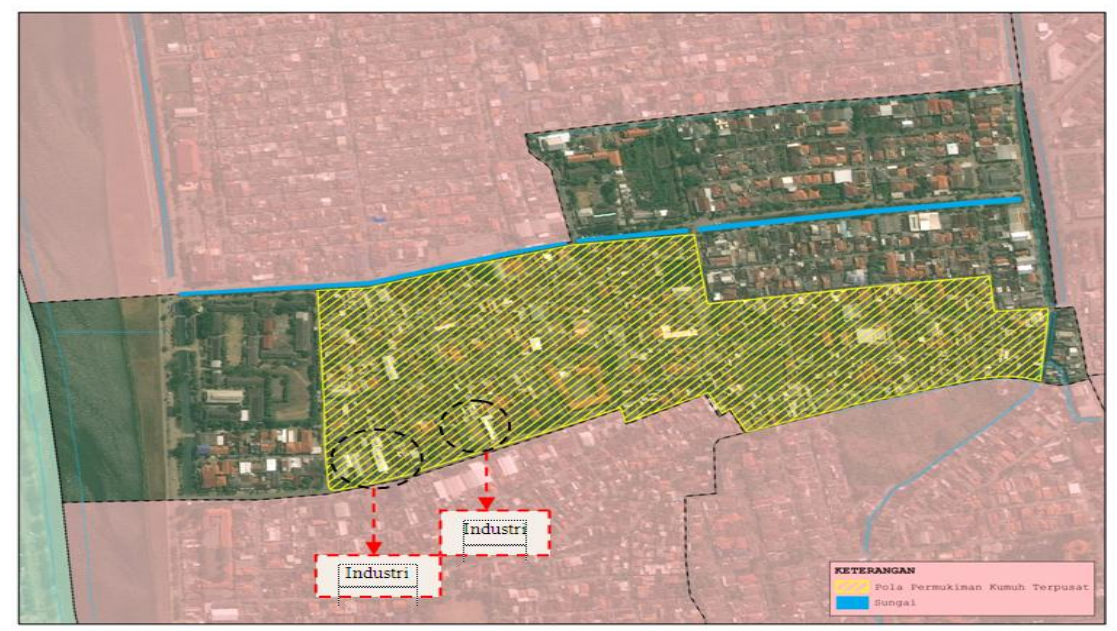

Gambar 10. Peta Pola Sebaran Permukiman Kumuh Kelurahan Panggung Kidul Sumber: Hasil Analisis, Tahun 2018 
Sebaran permukiman kumuh di Kelurahan Panggung kidul membentuk pola permukiman terpusat atau mengelompok yang didalam kawasannya terdapat sungai dan industri, sebaran permukiman juga dipengaruhi dengan adanya tanah atau lahan legal yang dulunya belum dimanfaatkan sehingga banyak rumah kumuh yang dibangun di atas lahan tersebut menjadikan tumbuhnya permukiman kumuh.Tanah atau lahan legal yang belum dimanfaatkan ini pada kondisinya berada dekat dengan sungai dan industri sehingga banyak bangunan yang dibangun dengan kondis padat dengan ruang-ruang yang sempit.

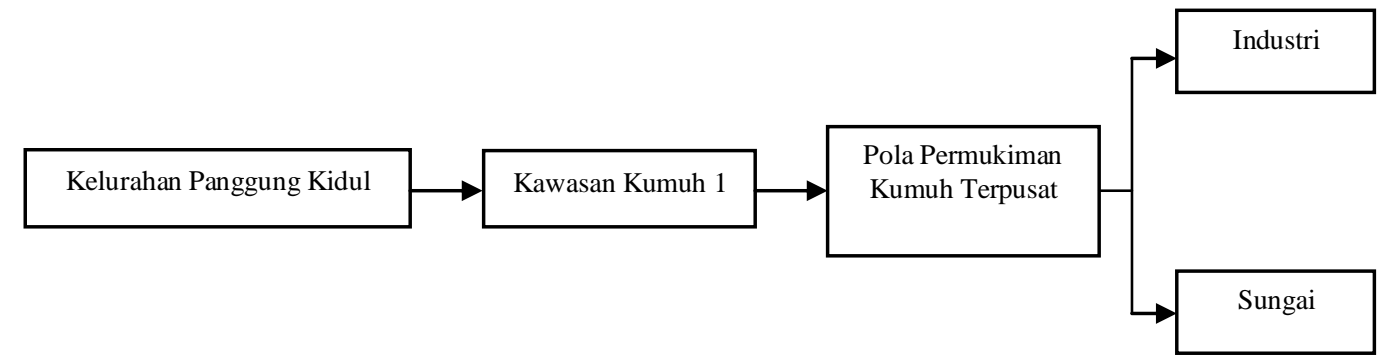

Gambar 11. Diagram Pola Sebaran Permukiman Kumuh Kelurahan Panggung Kidul Sumber: Hasil Analisis, Tahun 2018

\section{Pola Sebaran Permukiman Kumuh Kelurahan Purwosari.}

Pada Kelurahan Purwosari terdapat dua titik sebaran permukiman kumuh yang membentuk pola permukiman kumuh linier mengikuti sempadan sungai dan permukiman kumuh linier mengikuti jalur kereta api. Masyarakat di kawasan ini membangun rumah dengan menyesuaikan diri pada keadaan lokasi tersebut, yang dimana terdapat sungai dan jalur rel kereta api yang memanjang melintasi Kelurahan Purwosari. Lahan-lahan di sempadan sungai maupun di sempadan rel kereta api tersebut merupakan lahan milik pihak irigasi dan pihak PT. KAI yang dimanfaatkan oleh warga untuk mendirikan bangunan di kawasan tersebut, bangunan yang di dirikan warga merupakan bangunan-bangunan semi permanen dengan kepadatan bangunan dan kepadatan penduduk yang tinggi hingga akhirnya membentuk suatu permukiman kumuh.

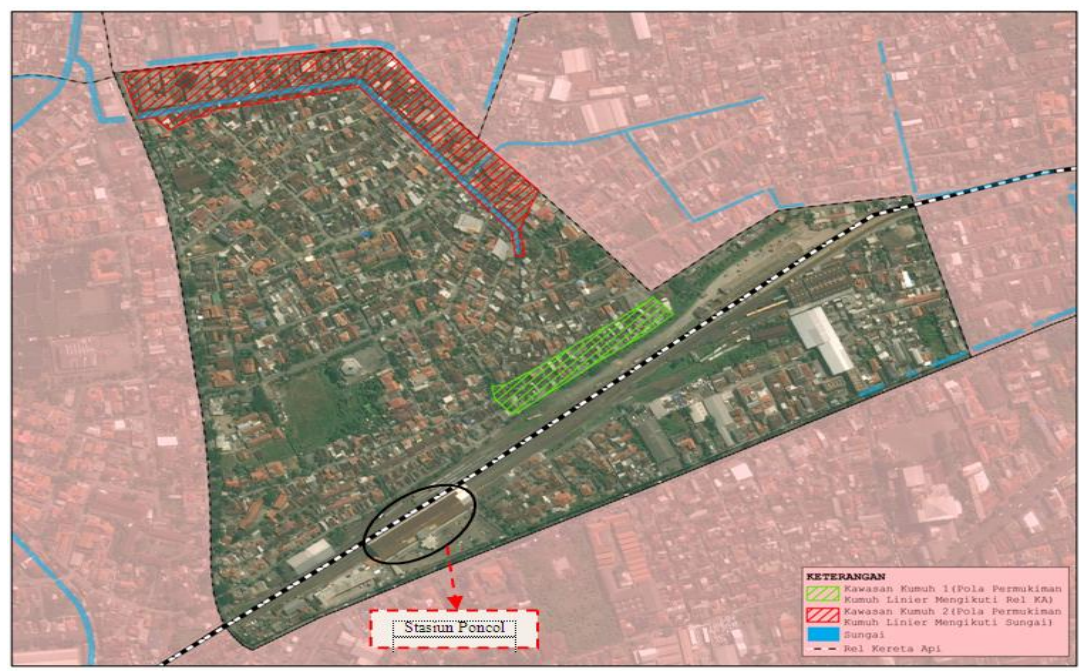

Gambar 12. Peta Pola Sebaran Permukiman Kumuh Kelurahan Purwosari Sumber: Hasil Analisis, Tahun 2018 
Sebaran permukiman kumuh di Kelurahan Purwosari ini membentuk pola permukiman kumuh linier mengikuti jalur sungai dan permukiman kumuh linier mengikuti jalur rel kereta api yang didalam kawasannya dilalui oleh kedua hal tersebut, sebaran permukiman juga dipengaruhi dengan adanya tanah atau lahan kosong ilegal milik pemerintah yang dulunya belum dimanfaatkan sehingga banyak rumah tidak layak huni yang dibangun di atas lahan tersebut menjadikan tumbuhnya permukiman kumuh

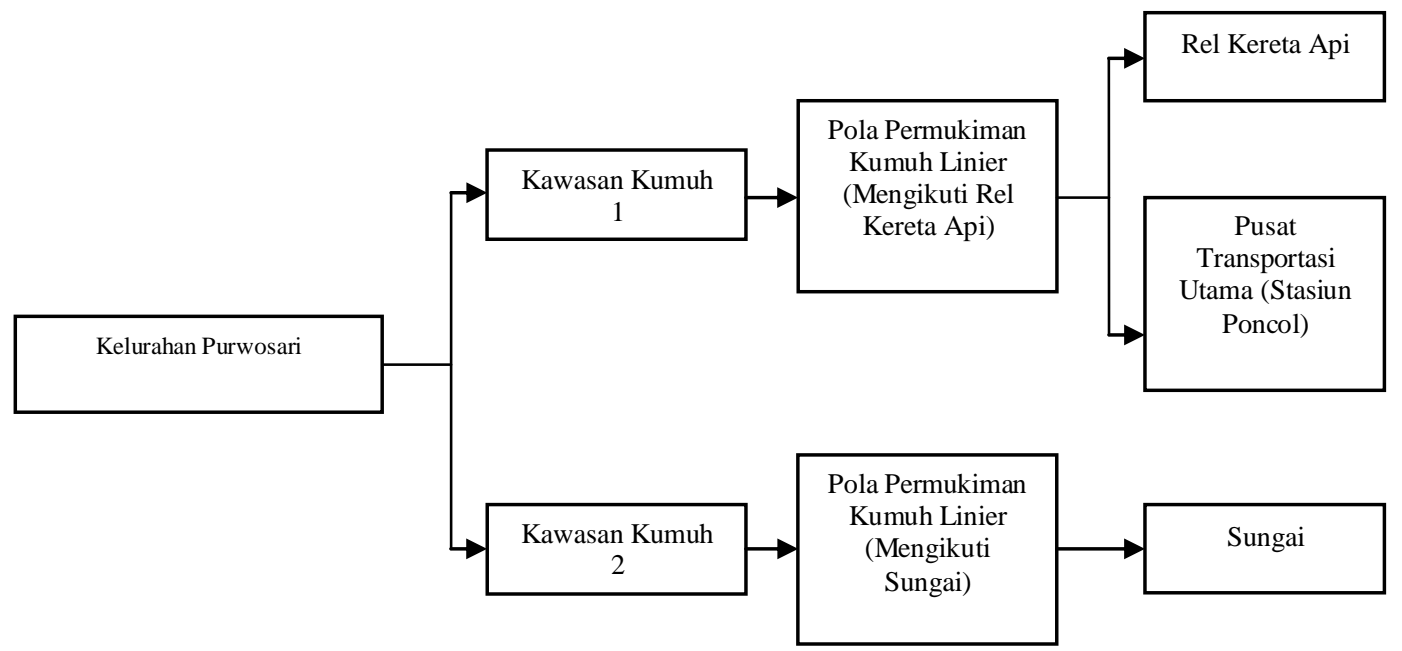

Gambar 13. Diagram Pola Sebaran Permukiman Kumuh Kelurahan Purwosari Sumber: Hasil Analisis, Tahun 2018 


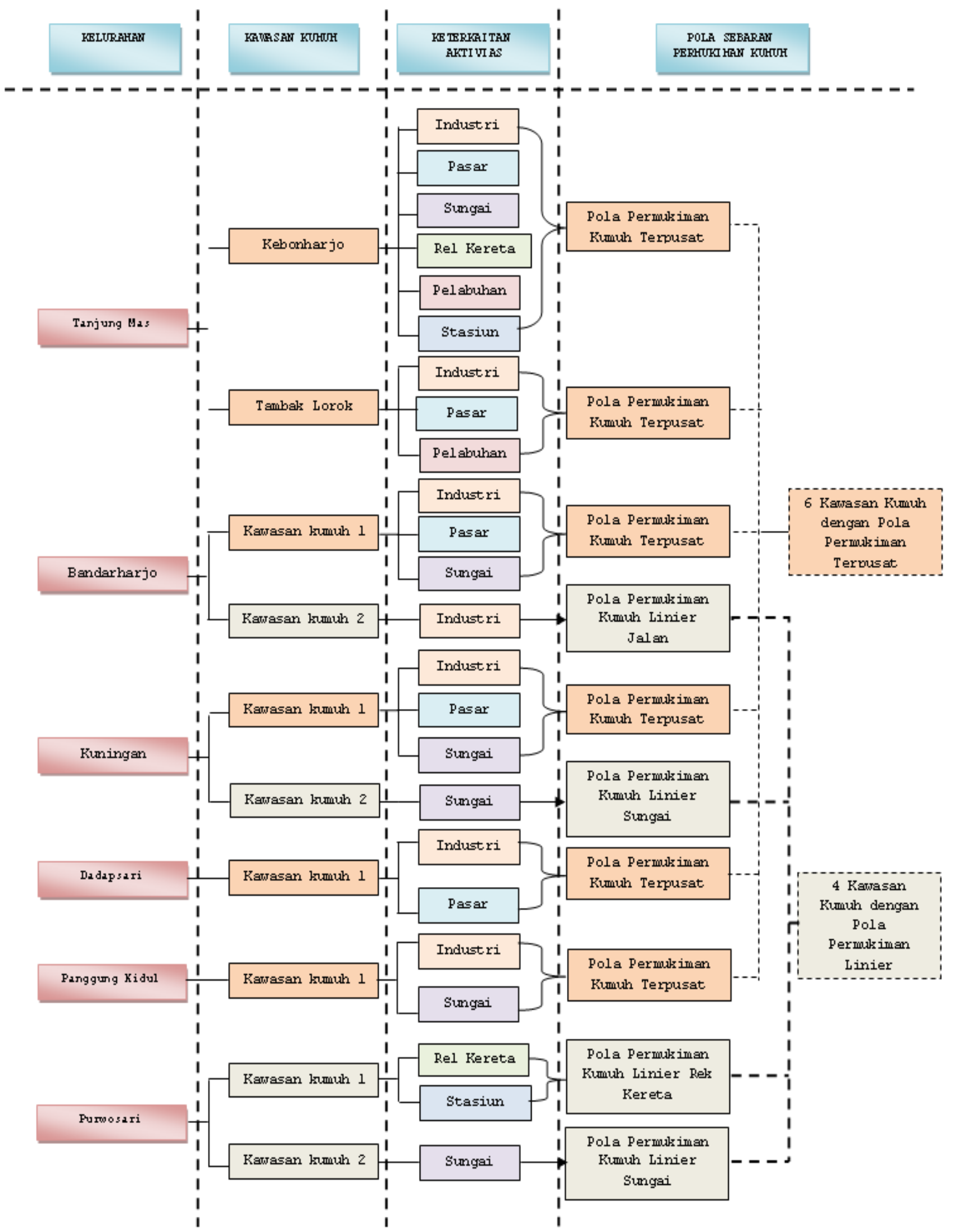

Gambar 14. Diagram Pola Sebaran Permukiman Kumuh Kecamatan Semarang Utara Sumber: Hasil Analisis, Tahun 2018 


\section{KESIMPULAN}

Sebaran permukiman kumuh di Kecamatan Semarang Utara terdiri atas 10 titik kawasan permukiman kumuh diantaranya Kelurahan Tanjung Mas yang terdiri atas 2 titik kawasan permukiman kumuh yaitu kawasan Kebonharjo dan kawasan Tambak Lorok yang membentuk pola sebaran permukiman kumuh terpusat atau mengelompok. Kelurahan Bandarharjo yang terdiri atas 2 titik kawasan permukiman kumuh yang terbagi atas pola sebaran permukiman kumuh linier mengikuti jalan dan pola sebaran permukiman kumuh terpusat atau mengelompok.Kelurahan Kuningan yang terdiri atas 2 titik kawasan permukiman kumuh yang terbagi atas pola sebaran permukiman kumuh linier mengikuti sungai dan pola sebaran permukiman kumuh terpusat atau mengelompok.Kelurahan Dadapsari terdapat 1 titik kawasan permukiman kumuh yang membentuk pola sebaran permukiman kumuh terpusat atau mengelompok. Kelurahan Panggung Kidul terdapat 1 titik kawasan permukiman kumuh yang membentuk pola sebaran permukiman kumuh terpusat atau mengelompok, dan Kelurahan Purwosari yang terdiri atas 2 titik kawasan permukiman kumuh yang terbagi atas pola sebaran permukiman kumuh linier mengikuti sungai dan pola sebaran permukiman kumuh linier mengikuti jalur kereta api.

Kawasan permukiman kumuh tersebut cenderung tumbuh mendekati sekitar kawasan industri, sekitar kawasan pasar, sekitar sempadan sungai, sarana transportasi utama (Pelabuhan Tanjung Mas dan Stasiun Tawang) dan jalur rel kereta api. Sekitar 7 dari 10 kawasan kumuh di Kecamatan Semarang Utara tumbuh mendekati daerahperindustrian, 7 kawasan permukiman kumuh mendekati sempadan sungai, 5 kawasan kumuh mendekati pasar, 3 kawasan kumuh mendekati sarana transportasi utama (pelabuhan Tanjung Mas, stasiun Tawang dan stasiun Poncol) dan 2 kawasan kumuh mendekati jalur rel kereta api.

\section{DAFTAR REFERENSI}

Auliannisa, Dywangga. (2009). Permukiman Kumuh Di Kota Bandung.Skripsi Fakultas Matematika dan Ilmu Pengetahuan Alam Departemen Geografi.Universitas Indonesia.

Gumilang, Galang Surya."Metode Penelitian Kualitatif Dalam Bidang Bimbingan \& Konseling.Jurnal Fokus Konseling Universitas Nusantara PGRI Kediri.Vol.2 No.2(2016):145.

Landoala, Tasrif. (2013). Pola Permukiman. Diakses 27 Juli 2017 dari http://jembatan4.blogspot.co.id/2013/08/pola-permukiman.html

Muhadjir, Noeng. (1996). Metodologi Penelitian Kualitatif. Yogyakarta: Penerbit Rake Sarasin.

Nazir, Mohammad. (1998). Metode Penelitian. Jakarta: Ghalia Indonesia

Novitasari, Shella. (2011). Keadaan Sosial Ekonomi Penduduk Berdasarkan Pola Permukiman Linier dan Mengelompok Disekitar Sungai Ogan, Provinsi Sumatera Selatan. Depok: Skripsi Fakultas Matematika Dan Ilmu Pengetahuan Alam Departemen Geografi. Universitas Indonesia.

Pasundanie, Adhinda P. A. (2009). Pola Permukiman Eks Karyawan BPM Di Tarakan.Tesis Universitas Brawijaya.

Pemerintah Indonesia (2014).Surat Kepurusan (SK) Walikota Semarang No.050/801/2014 Tentang Penetapan Lokasi Lingkungan Perumahan dan Permukiman Kumuh di Kota Semarang. Semarang.

Surtiani, Eny Endang. (2006). Faktor-Faktor yang Mempengaruhi Terciptanya Kawasan Permukiman Kumuh di Kawasan Pusat Kota (Studi Kasus : Kawasan Pancuran, Salatiga). Tesis Program Pascasarjana Magister Teknik Pembangunan Wilayah Dan Kota. Universitas Diponegoro.

Wulan, Anggun S. Kartika. (2016). Pengembangan Kampung Di Desa Karangwuni, Kecamatan Wates, Kulon Progo Berbasis Ekokultur.Skripsi Program Studi Arsitektur Fakultas Teknik.Universitas Atma Jaya Yogyakarta. 